\title{
Development of alder (Alnus glutinosa) coppice
}

T. W. M. Meeuwissen and H. Rottier (Department of Silviculture, Agricultural University, P.O. Box 342, $6700 \mathrm{AH}$ Wageningen, Netherlands)

Received 25 June 1984; accepted 20 July 1984

\begin{abstract}
In a study on marsh vegetation in the Netherlands attention was paid to current and former management, woody biomass and stand structure of four alder coppices. This was done with a view to the needs of the Nature Conservation Service.

Key-words: biomass, stand structure, forest management, nature conservation, alder, Alnus glutinosa
\end{abstract}

Introduction. Four alder stands ranged in age from 30 to more than 120 years and had not been coppiced for 30 to 50 years. They were therefore developing towards high forest highly even in age. By measuring the woody biomass and studying the structure of these ecologically similar coppices, suggestions could be made on further management.

Methods. Woody biomass was taken to include living and dead woody biomass, the latter including litter and standing dead timber. Living woody biomass was estimated with regression equations by inventory of representative plots. Dead woody biomass was estimated by weighing samples. Current annual increment was estimated from increment borings of trees of average basal area.

For stand structure, transects of $10 \mathrm{~m} \times 30 \mathrm{~m}$ were laid out in each stand on a north-south axis. Each tree and shrub higher than $1.50 \mathrm{~m}$ was drawn to scale in crown projection and side view.

Results. The transect drawings showed that the first structural set (Hallé et al., 1978), i.e. the trees constituting the forest crown, could be analysed at two levels:

(1) without making a distinction between the shoots growing out from one stump but only between stumps

(2) making a distinction between shoots growing out from each stump, so that each stump is regarded as producing a small forest.

A second structural set had not usually developed, but had occurred with natural thinning, and so could be induced by artificial thinning.

Results of the biomass determination are found in Table 1.

Discussion. According to the data in Table 1, all four coppices were in the aggrading (build-up) phase (Bormann \& Likens, 1979). The great difference in living biomass can partly be explained by a reorganization (recovery) of the stump during 
Table 1. Biomass and increment expressed as dry matter.*

\begin{tabular}{llllll}
\hline Place & $\begin{array}{l}\text { Age } \\
\text { (years) }\end{array}$ & $\begin{array}{l}\text { Living } \\
(\mathrm{t} / \mathrm{ha})\end{array}$ & $\begin{array}{l}\text { Dead } \\
(\mathrm{t} / \mathrm{ha})\end{array}$ & $\begin{array}{l}\text { CAI } \\
(\mathrm{t} / \mathrm{ha} \\
\text { per year) }\end{array}$ & $\begin{array}{l}\text { MAI } \\
(\mathrm{t} / \mathrm{ha} \\
\text { per year) }\end{array}$ \\
Westerveentjc & 30 & 146.0 & 6.0 & 4.6 & 5.1 \\
t Waal & 50 & 83.7 & 5.4 & 3.5 & 1.8 \\
Zure Venen & 35 & 118.7 & 18.2 & 3.5 & 3.9 \\
Helveen & 30 & 107.1 & 11.6 & 3.9 & 4.0
\end{tabular}

* Age refers to time since last coppicing, estimated from historical data. CAI and MAI is current and mean annual increment.

shooting. The duration of reorganization was correlated with how long the area had been under coppice. The large living biomass in Westerveentje coppice is attributed to thinning. Since all coppices were in the aggrading phase, one might expect that a degradation phase would follow, possibly resulting in a treeless stage as part of the natural succession (Fig. 1). Such a trend would be accentuated by the evenaged nature of the coppices and by their very small area. The total biomass in $\mathrm{Ag}$ grading Phase $4(\mathrm{Ag} 4)$ is less than would be expected in a more natural succession where big trees with a large biomass constitute the end of a natural aggrading phase with a biomass equal to that at the end of stage $\mathrm{Ag} 5$.

If such woods are too small to maintain themselves with a maximum area of an estimated 10 ha the following management is suggested to maintain and gradually develop the stand to a more natural woodland, avoiding shock effects as far as possible.

The uniformity of age can be broken by interference in the first structural set, for

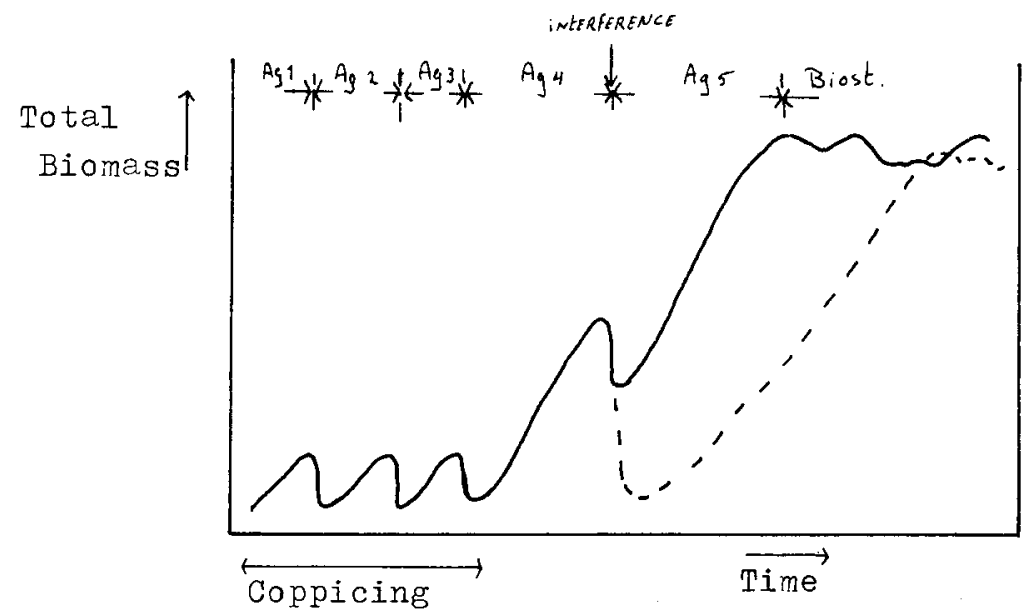

Fig. 1. Development of biomass in an alder forest after coppice management. The broken line represents natural development; the unbroken line development under management. Ag, aggrading phase; Biost., biostatic phase. 
instance by removing some shoots at various growing stages (level b of analysis). In this way, total biomass can be reduced and shoots will differ in age.

A differentiation in time and space of the developement phase may be so achieved. The smaller coppices, with an area less than about 10 ha, may need continuous supervision.

\section{References}

Bormann. F. H. \& G. E. Likens, 1979. Pattern and process in a forested ecosystem. Springer, New York. $253 \mathrm{pp}$

Hallé. F., R. A. A. Oldeman \& P. B. Tomlinson, 1978. Tropical trees and forests: an architectural analysis. Sprinter. Heidelberg. 441 pp.

This synopsis is based on an $M$. Sc. thesis entitled 'Geschiedenis, biomassa en structuur van enige elzenbossen, wilgen-, gagel-en kruipwilgstruwelen in Drenthe'. Department of Silviculture, Agricultural University, Wageningen, 1984. 136 pp., 40 figs., 6 tables, 37 refs., 4 appendices. Dutch.

Available as photocopies (order R017P, $f 40$ including postage) or microfiches (order R017M, f 17.50 including postage) at: NARD, clo Pudoc, P.O. Box 4, Wageningen, Netherlands (telex 45015 blhwg $\mathrm{hl}$ ).

\section{A matrix model of uneven-aged forest stands}

H. Rottier (Department of Forest Management, Agricultural University, P.O. Box 342, $6700 \mathrm{AH}$ Wageningen, Netherlands)

Received 25 June 1984; accepted 20 July 1984

Abstract. Matrix algebra showed that with uneven-aged stands allowable cut in a size class can be calculated from guessed number fractions of trees cut. The procedure can be used for calculation when optimization is impossible or not necessary. Key-words: Leslie matrix, uneven-aged stand, selective forest management, allowable cut.

Introduction. Forest in the Netherlands is sometimes managed on a small scale. The need arose to calculate allowable cut on a basis other than area. In the past attention has been concentrated on the ideal Liocourt curve (Knuchel, 1950; Meijer, 1980). Prodan (1949) indicated that the ideal curve depended on the cut. This idea is here developed into a general matrix model. 